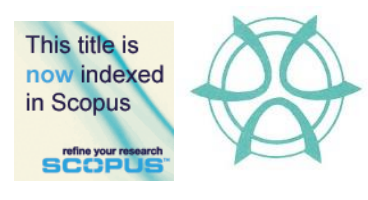

PLANNING MALAYSIA:

Journal of the Malaysian Institute of Planners

VOLUME 17 ISSUE 1 (2019), Page 48 - 57

\title{
COMPARISON ON ENERGY SAVING: GREEN ROOF AND GREEN WALL
}

\author{
Shazmin Shareena Ab. Azis ${ }^{1}$, Ibrahim Sipan², Maimunah Sapri ${ }^{3}$, Nurul Syakima \\ Mohd Yusoff ${ }^{4}$, \& Hariati Abdullah Hashim ${ }^{5}$ \\ 1,2,3,4,5 Faculty of Geoinformation \& Real Estate \\ UNIVERSITI TEKNOLOGI MALAYSIA
}

\begin{abstract}
Green building conveys undeniably numerous benefits to the environment, social and economic aspects. The most substantial benefit of green building is energy conservation. Green roofs and green walls are amongst the green components that are synonymous with green building. These green components are similar in nature as both are based on the concept of vegetation coverage on buildings. Vegetation is a well-known natural medium that performs the photosynthesis process where it releases molecular oxygen and removes carbon dioxide from the atmosphere. Many studies have proved that these two green components are efficient in reducing energy consumption of a building. Therefore, this study aims to examine and compare the annual energy savings conveyed by green roofs and green walls on residential buildings in Malaysia. The findings indicated that green walls provide greater annual energy savings than green roofs. The result shows that green walls are able to provide higher annual electricity savings for residential buildings at RM166 compared to green roofs, which provide savings of only RM139.
\end{abstract}

Keywords: green roof, green wall, energy saving, residential, Malaysia 
PLANNING MALAYSIA

Journal of the Malaysia Institute of Planners (2019)

\section{INTRODUCTION}

The building sector is greatly responsible for high energy consumption levels (Zimmermann, Althaus, \& Haas, 2005; Office of Energy Efficiency and Renewable Energy, 2010; Ismail, Al-Obaidi, \& Sulaiman, 2016). It was recorded that the trend of energy consumption for the building sector in Malaysia has risen at approximately 34\% from year 2005 to 2010 (Kwong, Adam, \& Sahari, 2014), and that yearly electricity consumption caused by air-conditioning was recorded as the highest among household appliances in Malaysia. The Malaysian national census reported that the total number of households with air-conditioning in Malaysia has dramatically increased from 13,000 units to 775,000 units from the year 1970 to year 2000. Therefore, the alarming increment in building energy consumption has triggered a green building movement around the world.

The integration of green roofs and green walls are synonymous with green building development. These green components are similar in nature as both are based on the concept of vegetation coverage on buildings. Vegetation is well-known as the natural medium that performs the photosynthesis process, where it releases molecular oxygen and removes carbon dioxide from the atmosphere. Both green components are able to provide energy savings on buildings. Several researches have shown that the integration of both green components have empirically proven to convey annual energy savings through reduced energy cooling demand of a building (Niachou, Papakonstantinou, Santamouris, Tsangrassoulis, \& Mihalakakou, 2001; Santamouris et al., 2007; Wong, Tan, Wong, Tan, \& Wong, 2009; Haggag, Hassan, \& Elmasry, 2014; Jaafar, Said, \& Rasidi, 2013). Hence, the applications of these green components are appropriate for countries that receive large amounts of sunlight including Malaysia. Therefore, this study pursues to analyse and compare the annual energy saving benefits conveyed by these green components. This study is important to provide an empirical proof of monetary savings via the energy saving benefits related to these green components on residential buildings in Malaysia. This study also plays a significant role in assisting and encouraging the integration of green roofs and green walls with residential buildings, as both green components are relatively new in Malaysia.

\section{THE CONCEPT OF GREEN ROOF AND GREEN WALL}

Green roofs consist of several layered systems, namely, the waterproofing membrane, the growing medium and the vegetation layer. Usually green roofs also consist of a root barrier layer, a drainage layer and an irrigation system (Sadineni, Madala, \& Boehm, 2011). There are two types of green roof setups, which are extensive roof and intensive roof. The difference between these roofs are mainly in the depth of the layer of substrate. Extensive roofs have a thinner layer of substrate which allows low level plants such as sedum or grass to nurture. On the other hand, intensive green roofs have a deeper substrate layer and allow 
deep rooting plants such as trees and shrubs to grow. Figure 1 below demonstrates the schematic representation of extensive and intensive green roof configurations.

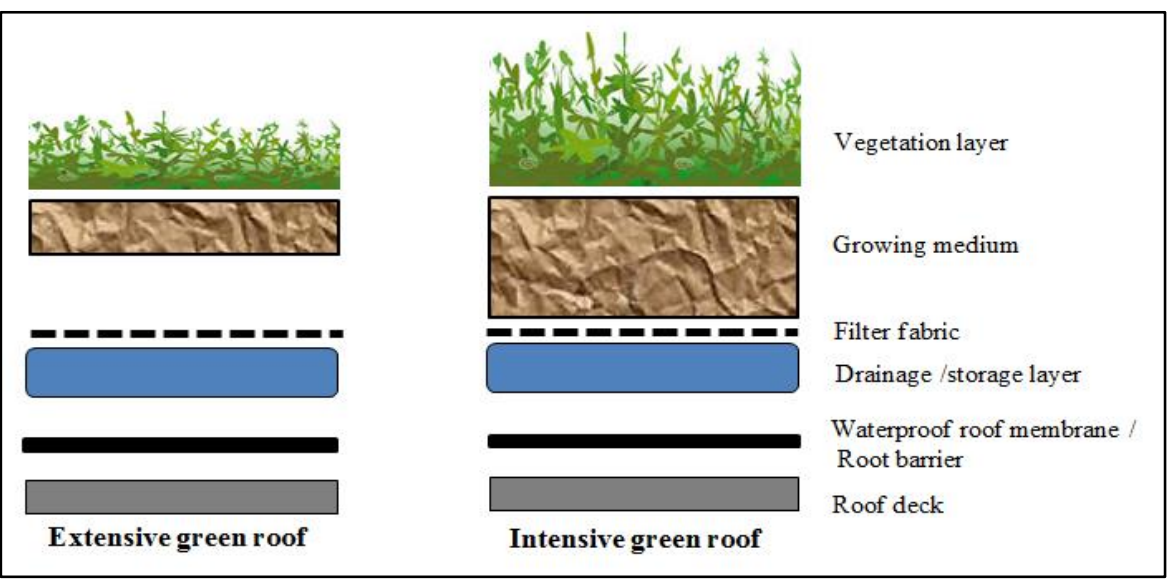

Figure 1: Schematic representation of extensive and intensive green roof configurations

Green wall is a concept which involves greening a vertical surface with a selection of plant species. Green wall systems can be divided into two, namely, green facade and living wall (Yu \& Hien, 2009; Manso \& Castro-Gomes, 2015). The prominent difference between the green facade and living wall systems is in the location of the growing media. Growing media is the place where nutrient for the plants' root is provided. Growing media that stays on the ground while the plants grow vertically over the vertical surface is called green facade (Binabid, 2010; Kontoleon \& Eumorfopoulou, 2010). Growing media that is spread over the vertical wall as a layer, on which the plants grow, is called living wall. Figure 2 below displays the variation types of green wall.

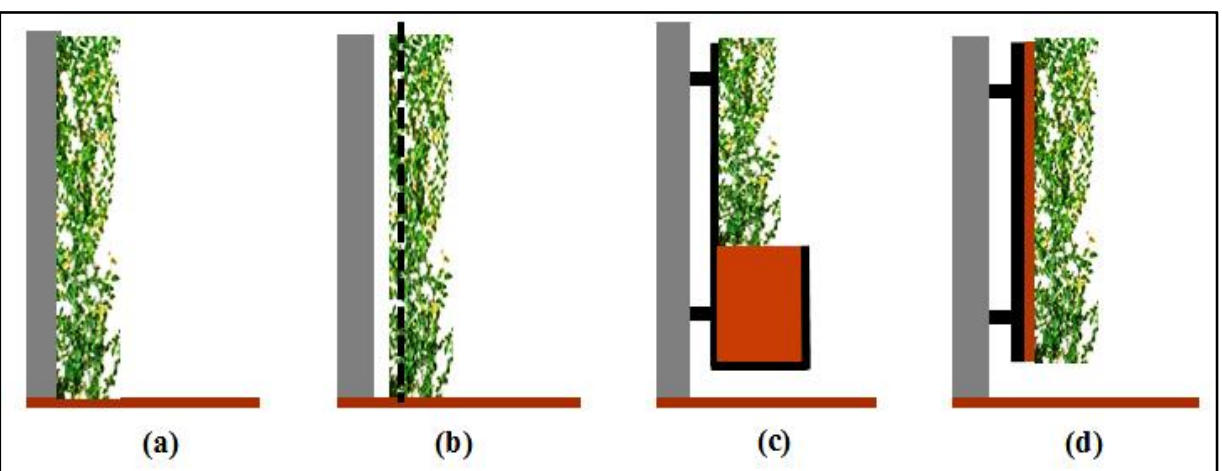

Figure 2: (a) Direct green facade; (b) Indirect green facade; (c) Indirect green facade with planter box; (d) Green living wall 
PLANNING MALAYSIA

Journal of the Malaysia Institute of Planners (2019)

\section{ENERGY SAVINGS OF GREEN ROOF}

Chen (2013) established that green roofs are generally built to enhance energy efficiency of buildings by preventing the penetration of solar heat into the building through the rooftop surface. Green roofs were verified to provide a cooling effect by reducing the indoor air temperature (Ismail et al., 2016). An experimental test and simulation was conducted by Santamouris et al. (2007) to investigate the performance of green roofs in reducing cooling and heating demand during summer and winter respectively. The experiment was conducted on a nursery school located near the centre of Athens. The layers of green roof installed on the rooftop of the first floor were made of local wild vegetation, soil substrates, and hydroponic stone wool for water storage; geotextile acted as the drainage layer and a polymeric membrane acted as water proofing and root repellent. The roof was $40 \%$ covered by the green roof system (Santamouris et al., 2007). The findings showed that the green roof system provided significant savings for cooling loads during summer but not during winter, where the findings on the heating load were insignificant. The study revealed that during summer, green roofs conveyed higher annual cooling load reduction on noninsulated buildings compared to insulated buildings at $15 \%$ to $49 \%$ respectively, for the whole building. The cooling load yielded even higher amounts of reduction for the first floor, which was positioned precisely under the green roof, at up to $76 \%$. Hence, this result explicitly suggested that the installation of green roofs provided energy savings in terms of cooling demands of the building (Santamouris et al., 2007).

Another study by Niachou et al. (2001) was conducted to investigate the thermal properties as well as the energy efficiency of a green roof system upon a building in Athens. The study indicated that green roofs on non-insulated buildings provided better thermal performance compared to well-insulated buildings. The study documented a significant exterior roof surface temperature reduction due to the existence of green roofs, as compared to bare roofs, by $10^{\circ} \mathrm{C}$. It was found that the indoor air temperature with green roofs was lower by $2^{\circ} \mathrm{C}$ compared to bare roofs. The surface temperature of the green roof varied according to the types of vegetation analysed by the study. Thick, dark green vegetation created lower temperatures compared to sparse red vegetation and bare ground soil alone at up to $29^{\circ} \mathrm{C}, 38^{\circ} \mathrm{C}$ and $40^{\circ} \mathrm{C}$ respectively.

The heat transfer coefficient of non-insulated green roofs was found to be better compared to insulated buildings at $16 \mathrm{~W} /\left(\mathrm{m}^{2} \mathrm{~K}\right)$ and $0.06 \mathrm{~W} /\left(\mathrm{m}^{2} \mathrm{~K}\right)$, respectively. This result indicated that green roofs of non-insulated buildings have better thermal resistance than insulated roofs. Furthermore, the study evidently verified that the annual energy savings for green roofs on non-insulated buildings was at $37 \%$ and had the potential to increase to $48 \%$ when the night ventilation of air change rate per hour (ACH) of 10 was applied (Niachou et al., 2001). 
An experimental study was conducted upon a green roof system on top of a low rise five storey commercial building with a roof area of $966 \mathrm{~m}^{2}$. The study was conducted under the hot and humid climate of Singapore. The findings highlighted that the installation of green roofs is significant in reducing thermal heat transfer and it also reduces energy consumption of a building. The study proved that the installation of green roofs could result in annual energy consumption savings of up to $15 \%$. The study also indicated that for space peak cooling loads, green roofs are able to provide savings of $17 \%$ to $79 \%$ (Wong et al., 2003).

An experimental field study was conducted in order to determine the effect of green roofs on the annual energy requirements for cooling and electricity usage. The study was carried out by Permpituck and Namprakai (2012) on a concrete slab roofing model. The field measurement result confirmed that thermal mass can decrease heat transfer into the building. The heat transfer decreases as the soil thickness increases. It was recorded that rooftops with soil depth of $0.1 \mathrm{~m}$ and $0.2 \mathrm{~m}$ could achieve up to $46 \%$ and $94 \%$ less heat transfer respectively, compared to exposed rooftops. Moreover, the annual energy consumption of rooftops with soil thickness of $0.1 \mathrm{~m}$ and $0.2 \mathrm{~m}$ was found to be less as compared to exposed rooftops, at $15 \%$ and $21 \%$ respectively.

The study also proved that lawn or vegetation planted on the green roof provides evaporative cooling for the building. Rooftops with soil thickness at $0.1 \mathrm{~m}$ planted with savannah grass achieved $9.6 \%$ less heat transfer than bare soil and $23 \%$ less than the exposed concrete slab. Meanwhile, rooftops with soil thickness at $0.2 \mathrm{~m}$ planted with savannah grass achieved less heat transfer compared to those planted with manila grass, at $8.8 \%$. Overall, it was recorded that the annual energy consumption of buildings with green rooftops with $0.1 \mathrm{~m}$ and $0.2 \mathrm{~m}$ of soil thickness, was $31 \%$ and $37 \%$ less respectively, than that of buildings with exposed roof surface. The lowest annual energy consumption for a building for cooling demand was found on a green roof system with $0.2 \mathrm{~m}$ wet soil thickness planted with savannah grass at $279 \mathrm{kWh}$.

Rumana and Hamdan (2009) through their study indicated that the application of potted plants is less efficient compared to growing plants directly on the rooftop. Therefore, based on several empirical studies, it can be inferred that green roofs are able to provide annual energy savings of about $15 \%$ to $49 \%$ for buildings.

\section{ENERGY SAVINGS OF GREEN WALL}

Wong et al. (2009) conducted a study on vertical greenery system or green facade system to identify the effects of vertical greenery systems on the temperature and energy consumption of a building. The results indicated that vertical greenery provides a passive cooling effect for the building and thus reduces the energy cooling load for the building. It was found that greenery coverage is the crucial 
PLANNING MALAYSIA

Journal of the Malaysia Institute of Planners (2019)

factor in determining the cooling load provided by the vertical greenery system. The study reported that the vertical greenery system was found to be able to reduce energy cooling load demand by approximately $32 \%$, depending on the greenery coverage on the system.

Haggag et al. (2014) revealed that green living walls reduced indoor air temperature under the hot and arid climate of Abu Dhabi. The study was conducted on an in situ living wall on a school building. The living wall was constructed using plastic planter boxes with dimensions of $30 \mathrm{~cm} \times 30 \mathrm{~cm} \times 25 \mathrm{~cm}$, which were attached permanently on the external surface of the wall structure, which was layered with waterproof membranes, equipped with drip irrigation and covered with plant foliage. The study compared the thermal performance of the living wall with the bare wall. It was found that the living wall could reduce the peak time indoor temperature by at least $5^{\circ} \mathrm{C}$ during the hottest month in July. The study also quantified the savings for cooling load. The cooling load reduced from 1.35 MWh to $1.07 \mathrm{MWh}$, resulting in 20\% energy savings for cooling via the deployment of a green wall (Haggag et al., 2014).

Kontoleon and Eumorfopoulou (2010) conducted an experimental study on the influence of the orientation of green walls on the thermal performance of a building. The study modelled a green wall with $20 \mathrm{~cm}$ thickness placed on four directions of a building, during summer time in Greece; specifically, north wall, south wall, east wall and west wall. The finding indicated that the west oriented wall had the highest annual cooling load at $18 \%$.

Wong, Tan, Tan, Chiang and Wong (2010) conducted an experimental study to investigate the thermal performance among several configurations of vertical green facade under the tropical climates of Singapore. There were 8 configurations of vertical green facades analysed in the study and 1 bare concrete wall without vegetation as a control wall. All facades were made of concrete walls with width, height and thickness of $4 \mathrm{~m}, 8 \mathrm{~m}$ and $0.3 \mathrm{~m}$ respectively. The study concluded that grid and modular panels are the best green wall configurations that could be used to reduce the facade temperature under hot and humid climates. Therefore, based on several empirical studies, it is concluded that the integration of green living walls with buildings is able to provide annual energy savings of about $18 \%$ to $32 \%$.

\section{METHODOLOGY}

The first objective is to scrutinize annual energy savings conveyed by green roofs and green walls based on the electricity consumption of residential buildings in Malaysia. The percentage of annual energy savings conveyed by green roofs and green walls was mainly derived from published empirical field and experimental findings that were conducted under hot and humid climates which are comparable to the Malaysian climate. This data was gathered and analysed using metaanalysis. Meta-analysis is aimed at synthesizing different studies that are 
independent of one another but are also compatible. This process makes it possible to provide new perspectives on a particular subject.

In order to translate this percentage into annual electricity savings, the average annual electricity consumption for residential buildings in Malaysia was determined. The average monthly energy usage for residential buildings is in Kilowatt hours per month (kWh/month). The percentage was then converted into total annual amount of energy reduction in $\mathrm{kWh}$. The total amount of energy reduction $(\mathrm{kWh})$ was multiplied with the current electricity tariff for residential buildings to determine the annual electricity savings conveyed by both green components. Figure 3 below demonstrates the flow to determine monetary annual energy savings in electricity bills conveyed by green roof and green wall systems.

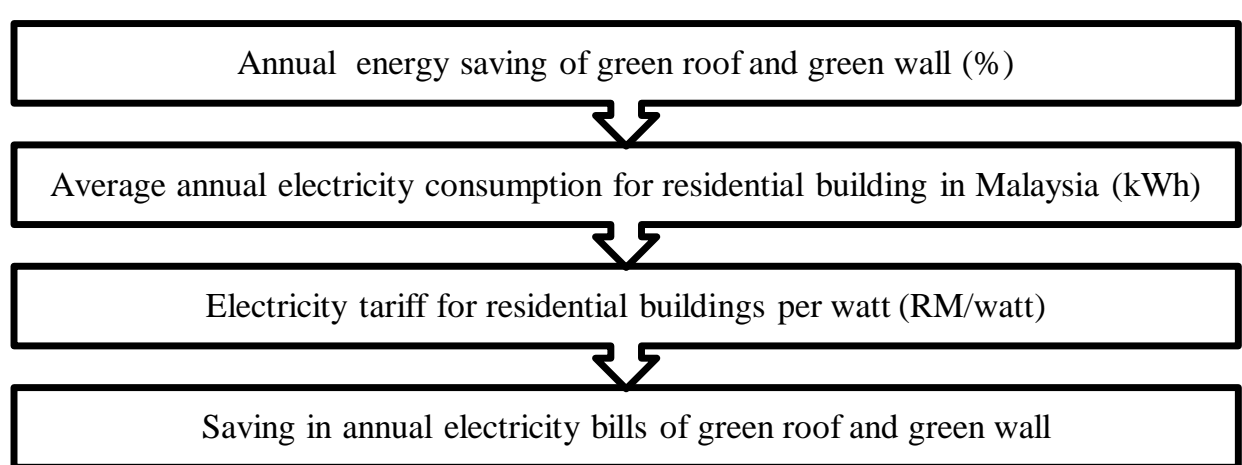

Figure 3: Methodology to determine annual electricity saving of green roof and green wall

\section{FINDINGS ON ANNUAL ENERGY SAVINGS OF GREEN ROOFS AND GREEN WALLS}

The annual energy savings of green roof and green wall systems were calculated based on the average energy consumption of residential buildings in Malaysia. The charges or tariff of the electricity varies according to the level of electrical usage of each residential building. The range of electrical tariff starts from RM $0.218 /$ watt for the first $200 \mathrm{kWh}$ monthly to RM $0.454 /$ watt for $901 \mathrm{kWh}$ onwards monthly. The monthly minimum charge for electricity bill is RM 3.

The average electricity consumption for residential properties in Malaysia is about $350 \mathrm{kWh}$ per month which is equal to $4200 \mathrm{kWh}$ per year. Therefore, the average electricity usage for residential buildings in Malaysia is assessed at $4200 \mathrm{kWh}$ per year. This indicates that the average annual electricity bill for residential buildings in Malaysia is RM 1,225 per annum. Table below shows the calculation for the savings in electricity consumption and monetary savings in annual electricity bills conveyed by green roof and green wall systems. This study adopted the minimum percentage of annual energy saving conveyed 
by green roofs and green walls. The calculation is based on the minimum annual energy savings. The formula for the calculation is as below.

$$
\begin{array}{cll}
\text { Annual electricity } & \text { saving }(\mathrm{RM})=\text { AES } \times \text { AEC x Tariff } \\
\text { AES }= & \text { Minimum annual energy saving }(\%) \\
\text { AEC }= & \text { Average annual electricity consumption }(\text { Kwh }) \\
\text { Tariff }= & \text { Electricity rates for residential }(\mathrm{RM})
\end{array}
$$

Table 1: Annual saving in electricity consumption conveyed by green roof and green

\begin{tabular}{ccccc}
\hline $\begin{array}{c}\text { Green } \\
\text { envelope } \\
\text { components }\end{array}$ & $\begin{array}{c}\text { Minimum } \\
\text { annual energy } \\
\text { saving } \\
(\%)\end{array}$ & $\begin{array}{c}\text { Average } \\
\text { annual energy } \\
\text { consumption } \\
(\mathrm{kWh})\end{array}$ & $\begin{array}{c}\text { Annual saving in } \\
\text { electricity } \\
\text { consumption } \\
(\mathrm{kWh})\end{array}$ & $\begin{array}{c}\text { Annual } \\
\text { electricity } \\
\text { bills saving } \\
(\mathrm{RM})\end{array}$ \\
\hline Green wall & 18 & 4200 & 756 & 166 \\
Green roof & 15 & 4200 & 630 & 139 \\
\hline
\end{tabular}

From the table above, it can be seen that the minimum amount of annual electricity savings conveyed by green roof and green wall setups based on average electricity consumption of residential buildings in Malaysia, are RM 139 and RM 166, respectively. This finding clearly shows that the integration of green walls with residential buildings is able to produce more electricity bill savings as compared to green roofs. The finding shows that the integration of green walls is able to reduce the bill by RM 166 per year which is about RM 27 more than the annual energy savings of green roofs. This finding is interesting as it proves that the integration of green walls may surpass the annual energy saving benefits conveyed by green roofs. This implies that the application of green walls is appropriate and significant for a country like Malaysia, which receives a large amount of sunlight per year. Nevertheless, the integration of green roofs is also considered as beneficial in conveying annual energy savings of RM 139 at minimum.

\section{CONCLUSION}

This study measures and compares the annual energy savings provided by green roofs and green walls on residential buildings in Malaysia. The estimation was based on the average annual energy consumption of residential buildings in Malaysia. This study has statistically proven that the integration of both green roofs and green walls is significant and appropriate for countries like Malaysia that receive a large amount of sunlight per year. The outcome has shown that the integration of green walls provides greater annual electricity savings compared to green roofs. 


\section{REFERENCES}

Binabid, J. (2010, May). Vertical garden: The study of vertical garden and their benefits for low rise building in moderate and hot climates. High Performance Building Enclosures - Practical Sustainability Symposium. May 1, 2010, Pomona, California, USA.

Chen, C. F. (2013). Performance evaluation and development strategies for green roofs in Taiwan: A review. Ecological Engineering, 52, 61-68.

Office of Energy Efficiency and Renewable Energy (2010). Building energy data book. Washington, DC: Department of Energy.

Haggag, M., Hassan, A., \& Elmasry, S. (2014). Experimental study on reduced heat gain through green facades in a high heat load climate. Energy and Buildings, 82, 668-674.

Ismail, M. A., Al-Obaidi, K. M., \& Sulaiman, R. (2016). Energy efficiency policy for existing typical campus buildings in the University of Malaya. Planning Malaysia, Special Issue 4, 129-144.

Jaafar, B., Said, I., \& Rasidi, M. H. (2013, November). Evaluating the impact of vertical greenery system on cooling effect on high rise buildings and surroundings: a review. 12th International Seminar on Environment and Architecture. November 10-11, 2011, East Java, Indonesia.

Kontoleon, K. J., \& Eumorfopoulou, E. A. (2010). The effect of the orientation and proportion of plant-covered wall layer on the thermal performance of a building zone. Built Environment, 45(5), 1287-1303.

Kwong Q. J., Adam N. M., \& Sahari B. B. (2014). Thermal comfort assessment and potential for energy efficiency enhancement in modern tropical buildings: A review. Energy and Buildings, 68(Part A), 547-557.

Manso, M., \& Castro-Gomes, J. (2015). Green wall systems: A review of their characteristics. Renewable and Sustainable Energy Reviews, 41, 863-871.

Niachou, A., Papakonstantinou, K., Santamouris, A., Tsangrassoulis, A., \& Mihalakakou, G. (2001). Analysis of the green roof thermal properties and investigation of its energy performance. Energy and Buildings, 33(7), 719-729.

Permpituck, S., \& Namprakai, P. (2012). The energy consumption performance of roof lawn gardens in Thailand. Renewable Energy, 40(1), 98-103.

Rumana, R., \& Hamdan, M. A. (2009). The passive cooling effect of green roof in high rise residential building in Malaysia. Sustainable Architecture and Urban Development, 1, 271-282.

Sadineni, S., Madala, S., \& Boehm, R. F. (2011). Passive Building energy savings: A review of building envelope components. Renewable and Sustainable Energy Reviews, 15(8), 3617-3631.

Santamouris, M., Pavlou, C., Doukas, P., Mihalakakou, G., Synnefa, A., Hatzibiros, A., \& Patargias, P. (2007). Investigating and analysing the energy and environmental performance of an experimental green roof system installed in a nursery school building in Athens, Greece. Energy, 32(9), 1781-1788.

Wong, N. H., Cheong, D. K. W., Yan, H., Soh, J., Ong, C. L., \& Sia, A. (2003). The effect of rooftop garden on energy consumption of a commercial building in Singapore. Energy and Buildings, 35(4), 353-364. 
Wong, N. H., Tan, A. Y. K, Tan, P. Y., Chiang, T., \& Wong, N. C. (2010). Acoustics evaluation of vertical greenery systems for building walls. Building and Environment, 45(2), 411-420.

Wong, N.H., Tan, A.Y.K., Wong, R., Tan, P.Y., Wong, N.C. (2009). Energy simulation of vertical greenery systems. Energy and Buildings. 41, 1401-1408.

Yu, C., \& Hien, W. (2009). Thermal impact of strategic landscaping in cities: A review. Advances in Building Energy Research, 3(1), 237-260.

Zimmermann, M., Althaus, H. J., \& Haas, A. (2005). Benchmarks for sustainable construction: A contribution to develop a standard. Energy and Buildings, $33(11), 1147-1157$

Received: $28^{\text {th }}$ October 2018. Accepted: $1^{\text {st }}$ March 2019 